\title{
Efficacy and Safety of the New Intravenous Immunoglobulin IGIV $10 \%$ in Adults with Chronic Idiopathic Thrombocytopenic Purpura
}

\author{
Gyula Varga $^{a} \quad$ Zuzana Volkováb ${ }^{b}$ H. Leiblc ${ }^{c}$ Zoltán Gasztonyi ${ }^{d} \quad{\text { Antonin Hlusie }{ }^{e} \text { Jiri Mayer }}^{f}$ \\ Krzysztof Chojnowskig Hans-Heinrich Wolfh Marlies Sharkhawyc Borislava G. Pavlovac \\ Karl Birthistle ${ }^{c}$ Werner Engl ${ }^{c}$ Simone Walter ${ }^{c}$ Hartmut J. Ehrlich ${ }^{c}$, and the ITP-IGIV 10\% Study \\ Group*
}

a University of Szeged, Szeged, Hungary

bInstitute of Haematology \& Blood Transfusion, Prague, Czech Republic

${ }^{c}$ Baxter, Vienna, Austria

dPetz Aladár Teaching Hospital, Györ, Hungary

e University Hospital, Olomouc,

f University Hospital, Brno, Czech Republic

g Medical University of Lodz, Lodz, Poland

${ }^{\mathrm{h}}$ Martin-Luther-Universität, Halle, Germany

\section{Key Words}

IGIV · Intravenous immunoglobulin - Idiopathic thrombocytopenic purpura . Chronic ITP

\section{Summary}

Background: Intravenous immunoglobulin (IGIV) $10 \%$ is a newly developed $10 \%$ liquid immunoglobulin preparation for intravenous use where 3 dedicat ed virus reduction steps have been integrated into the manufacturing process. The efficacy and safety of this product were assessed in a prospective multicenter study in chronic ITP (idiopathic thrombocytopenic purpura) patients with platelet counts of $\leq 20 \times 10^{9} / \mathrm{l}$. Patients and Methods: 23 adult ITP patients received the product at a total dose of $2 \mathrm{~g} / \mathrm{kg}$ body weight administered over 2-5 days, and were followed for 4 weeks. Results: Of the 21 subjects included in the Per-Protocol Analysis Data Set, 15 responded successful ly to treatment $(71.4 \%)$. Eleven subjects in this group attained a platelet count increase to $>100 \times 10^{9} / \mathrm{l}$, and 8 reached a platelet count of $>200 \times 10^{9} /$. All 15 responders achieved a platelet count of $\geq 50 \times 10^{9} / \mathrm{l}$ by day 8 , and 14 of them reached this level by day 5 . The median duration of platelet response was 25 days, and the highest median platelet count in the responders was $182 \times 10^{9} / \mathrm{l}$ A total of 81 infusions were administered to the 23 subjects in the Safety Analysis Data Set over the course of the study. There were 40 non-serious adverse events related to the use of the study drug - 35 mild, 3 moderate, and 2 severe. The most frequent related adverse events were headache and pyrexia. Conclusion: The results obtained in this study demonstrate that IGIV $10 \%$ is effective in the treatment of adult subjects with chronic ITP and indicate a good safety profile.

\section{Schlüsselwörte}

IGIV · Intravenöses Immunglobulin · Idiopathische thrombozytopenische Purpura · Chronische ITP

\section{Zusammenfassung}

Hintergrund: Intravenöses Immunglobulin (IGIV) 10\% ist ein neu entwickeltes $10 \%$ iges flüssiges Immunglobulinpräparat zur intravenösen Administration bei dessen Herstellung 3 spezifische Schritte zur Virusinaktivierung/-eliminierung zur Anwendung kommen. Die Wirksamkeit und Sicherheit dieses Präparats wurden in einer prospektiven, multizentrischen Studie in Patienten mit chronischer idiopathischer thrombozytopenischer Purpura (ITP) manifestiert durch eine Thrombozytenzahl von $\leq 20 \times 10^{9} / /$ nachgewiesen. Patienten und Methoden: 23 erwachsenen ITP-Patienten wurde eine Gesamtdosis von je 2 IGIV 10\% pro kg Körpergewicht über 2-5 Tage verteilt verabreicht. Der nachfolgende Beobachtungszeitraum erstreckte sich über 4 Wochen. Ergebnisse: Von den 21 Patienten, die die Kriterien laut Studienplan erfüllten, sprachen 15 $(71,4 \%)$ auf die Behandlung an. In 11 Patienten stiegen die Thrombozyten auf über $100 \times 10^{9} / \mathrm{l}$, in 8 konnte ein Anstieg auf über $200 \times 10^{9} / \mathrm{l}$ beobachtet werden. Alle 15 Responder hatten einen Anstieg auf mindestens $50 \times 10^{9} / \mathrm{l}$ bis zum Tag 8 nach Behandlungsbeginn, 14 davon bereits bis zum Tag 5. Der Median der Dauer des Responses auf die Produktgabe betrug 25 Tage, und der Median der maximalen in Respondern gemessenen Werte lag bei $182 \times 10^{9} /$. Die 23 Studienteilnehmer, die alle in die Auswertung zur Produktsicherheit einbezogen wurden, erhielten im Rahmen der Studie insgesamt 81 Infusionen. Von 40 berichteten nicht schwerwiegenden Nebenwirkungen wurden 35 als leicht, 3 als mäßig schwer und 2 als schwer klassifiziert. Die häufigsten dieser produktbedingten unerwünschten Ereignisse waren Kopfschmerz und Pyrexie. Schlussfolgerung: Die Ergebnisse der Studie zeigen die Wirksamkeit von IGIV $10 \%$ in der Behandlung Erwachsener mit chronischer ITP und das gute Sicherheitsprofil des Produkts.

\footnotetext{
* The EU-ITP-IGIV 10\% study group consists of: Zoltán Gasztonyi, Petz Aladár Teaching Hospital, Györ, Hungary; Frank Griesinger, Georg-August-Universität, Göttingen, Germany; Antonin Hlusi, University Hospital, Olomouc, Czech Republic; János Iványi, Markusovszky Hospital, Szombathely, Hungary; Jan Kvasnicka, Charles University, Prague, Czech Republic; Jaroslav Mal_, University Hospital, Hradec Králové, Czech Republic; Jiri Mayer, University Hospital, Brno, Czech Republic; Krzysztof Chojnowski, Medical University of Lodz, Lodz, Poland; Hans-Heinrich Wolf, Martin-Luther-Universität, Halle, Germany; Gyula Varga, University of Szeged, Szeged, Hungary; Zuzana Volková, Inst. Haematol. \& Blood Transfusion, Prague, Czech Republic; and from Baxter, Vienna, Karl Birthistle, Hartmut J. Ehrlich, Werner Engl, Sandor Fritsch,
} Cora Hiebinger, Heinz Leibl, Friedrich Maritsch, Borislava G. Pavlova, Marlies Sharkhawy, Simone Walter and Martin Wolfsegger. 


\section{Introduction}

Many patients and clinicians rely on therapeutic proteins, such as intravenous immunoglobulin (IGIV), isolated from human blood plasma. Even though the pathogen safety records for IGIV and other plasma proteins are excellent, ascertaining and ensuring pathogen safety of plasma-derived therapeutics continues to be a priority among manufacturers and health authorities [1-3]. From a pharmaco-economic point of view, the continued efforts to maintain and improve blood safety may go well beyond accepted norms of cost-effectiveness in medical interventions [4-6]. However, this approach has been singularly effective in managing agents traditionally considered to pose the highest risk to the patient [4]. As plasma remains predisposed to contamination by a variety of blood-borne pathogens including new or re-emerging infectious agents $[1-3,7]$, transfusion specialists and regulatory agencies are now focusing a similar degree of attention on emerging infections with a view to balancing the need for both the safety of the blood supply and the availability of lifesaving blood and blood products $[3,4]$.

The new $10 \%$ liquid immunoglobulin preparation, IGIV $10 \%$ (KIOVIG ${ }^{\mathrm{TM}}$, Baxter International Inc., Deerfield, IL, USA), was developed to provide a preparation with an increased margin of safety. Furthermore, formulation as a $10 \%$ liquid preparation offers the advantage of easier use by physicians, pharmacists, nurses and patients, and allows for smaller volumes of product to be infused (compared to $5 \%$ formulations). In the past, various state-of-the-art methods for virus reduction were developed and described in publications [8-19]. IGIV $10 \%$ is processed using 3 independent validated viral inactivation or removal steps: solvent/detergent (S/D) treatment, nanofiltration $(35 \mathrm{~nm})$, and low-pH incubation with elevated temperature.

Idiopathic thrombocytopenic purpura (ITP), also referred to as immune thrombocytopenic purpura, is a common clinical disorder of immune regulation: autoantibodies are produced against platelets, leading to phagocytic destruction of these cells [20-23]. Acute and chronic forms of ITP have been described. Acute ITP mainly occurs in children, often following a viral infection [24]. Chronic ITP is most often seen in adults and may last for years, and even indefinitely. The platelet count usually remains at one third to one half the normal value of $150-350 \times 10^{9} / 1$ but can also drop to very low levels. Chronic ITP rarely remits spontaneously. Treatments for ITP generally include corticosteroids, other immunosuppressive agents, anti-D immunoglobulin, IGIV and splenectomy [21, 25]. Since the initial report by Imbach et al. [26], several studies have confirmed the efficacy of high-dose treatment with IGIV infusions in patients with ITP [27]. The platelet count rises rapidly after immunoglobin treatment, and sustained platelet response has been observed in some patients [28, 29]. Various regimens have since been proposed for immunoglobulin treatment of patients with ITP. Originally, 5 daily doses of
$0.4 \mathrm{~g} / \mathrm{kg}$ body weight (total dose $2 \mathrm{~g} / \mathrm{kg}$ ) were administered [26, 30-33]. However, other treatment regimens $(1,000 \mathrm{mg} / \mathrm{kg}$ over 2 days) have also been described and reported to be successful in individual patients [27]. The efficacy and safety of high-dose treatment of adult chronic ITP patients with IVIG $10 \%$ were assessed in a prospective, multicenter study.

\section{Patients and Methods}

\section{Study Drug}

IGIV $10 \%$ is a ready-to-use liquid IGIV at $10 \% \mathrm{w} / \mathrm{v}$ protein concentration with a $\mathrm{pH}$ of 4.6-5.1, allowing for smaller volumes of product to be infused compared to traditional $5 \%$ products. The stabilizing agent is 0.25 $\mathrm{mol} / \mathrm{l}$ glycine. The product contains no preservatives and no glucose or sucrose. The manufacturing process of IGIV $10 \%$ is based on frozen human plasma and includes a modified Cohn-Oncley cold alcohol fractionation procedure and ion exchange chromatography steps. 3 dedicated virus reduction steps are included in the manufacturing process: i) incubation for $\geq 60$ min at $18-25{ }^{\circ} \mathrm{C}$ with a solvent-detergent mixture of $0.3 \%$ tri-n-butyl phosphate, $1.0 \%$ Triton $\mathrm{X}-100$, and $0.3 \%$ Tween 80 to inactivate lipid-enveloped viruses; ii) nanofiltration through $35 \mathrm{~nm}$ filters to remove enveloped and non-enveloped viruses and other pathogens by size exclusion; and iii) incubation of final container vials for $21-22$ days at $30-32{ }^{\circ} \mathrm{C}$ and a $\mathrm{pH}$ of 4.6-5.1 to neutralize enveloped and non-enveloped viruses.

\section{Subjects}

Adult subjects were eligible for enrolment in the study if they were diagnosed with ITP at least 6 months prior to study entry, and had a baseline platelet count of $\leq 20 \times 10^{9} / 1$ determined prior to administration of the study drug on the day of the first infusion. They should have had no IGIV treatment for ITP during the 2 weeks prior to the first infusion of the study drug. Exclusion criteria included but were not limited to: increased serum values of alanine aminotransferase (ALT), aspartate aminotransferase (AST), alkaline phosphatase, and/or total bilirubin, renal dysfunction, other underlying autoimmune or lymphoproliferative disorder, cardiac insufficiency, treatment with another investigational drug in the 4 weeks prior to study entry and history of severe adverse reactions to blood and/or blood products.

Eleven study sites in Germany, the Czech Republic, Hungary and Poland administered IGIV $10 \%$ to a total of 23 adult subjects with chronic ITP. Two of the subjects did not meet all selection criteria (one had a platelet count of $>20 \times 10^{9} / 1$, the other was diagnosed with ITP less than 6 months prior to study entry). Therefore, efficacy results were calculated separately for the subjects who received IGIV $10 \%$ and were monitored for platelet count (Full Analysis Data Set, FADS, $n=23$ ) and for the subjects who met all selection criteria, received IGIV $10 \%$ and were monitored for platelet count (Per-Protocol Analysis Data Set, PADS, $n=21$ ). The Safety Analysis Data Set (SADS) comprised all subjects who received IGIV $10 \%$ and was identical to the FADS $(n=23)$.

\section{Study Design}

The study was a prospective, open-label, non-controlled, multicenter study. Subjects eligible for treatment received a total dose of $2 \mathrm{~g} / \mathrm{kg}$ IGIV $10 \%$ administered over 2-5 days. A maximum of 2 booster doses, each ranging from 400 to $1,000 \mathrm{mg} / \mathrm{kg}$, were permitted if the platelet count dropped to $\leq 20 \times 10^{9} / 1$. During the first $30 \mathrm{~min}$, the infusion rate was not permitted to exceed $0.5 \mathrm{ml}(50 \mathrm{mg}) / \mathrm{kg} / \mathrm{h}$. If no adverse events (AEs) occurred, the infusion rate was gradually increased. The maximum infusion rate permitted was $8 \mathrm{ml} / \mathrm{kg} / \mathrm{h}$. Subjects who did not achieve at least one platelet increase to $\geq 50 \times 10^{9} / 1$ by day 15 after the onset of the treatment course, or who required a booster dose before day 15 , were considered non-responsive to study drug treatment and exited the study on day 15 . 
All other subjects were followed until day 29. Platelet counts were determined at screening and on days 1 (initiation of treatment course), 2, 5, 8, $11,15,22$, and 29. Blood samples for platelet determination on treatment days were drawn prior to study drug administration. Subjects already receiving corticosteroids at entry into the study could be continued on corticosteroid treatment in doses equivalent to $20 \mathrm{mg}$ or less of prednisone daily during the treatment and follow-up periods in the study. However, the dose had to be steady or decreasing during the study period.

The study was conducted in accordance with the principles of the Declaration of Helsinki (Somerset West 1996), the Note for Guidance on Good Clinical Practice (CPMP/ICH/135/95) and valid national laws. The clinical protocol was approved by the respective ethics committees and, after having been informed of the aspects of study participation, informed consent forms were signed by the study subjects.

\section{Evaluation of Efficacy and Safety}

The primary endpoint of the study was the number of treatment responders. A responder was defined as a subject who i) had a platelet increase to $\geq 50 \times 10^{9} / 1$ at least once prior to day 15 and ii) did not require a booster dose prior to day 15. Secondary endpoints were the time taken to achieve a platelet count of $\geq 50 \times 10^{9} / 1$, the duration of platelet response, the maximum platelet count, and regression of hemorrhages.

For evaluation of safety, all AEs occurring between the baseline visit and the end of the study were recorded. A Coombs' test was performed before the first infusion and on day 8 .

\section{Statistical Analysis}

The proportion of platelet count responders and a two-sided $95 \%$ confidence interval (CI) for the proportion was given using the Wilson score method without continuity correction [34]. The median and 95\% CI for the time taken to achieve predefined platelet response were estimated from the beginning of the first infusion until the first measurement of a platelet count of $\geq 50 \times 10^{9} / 1$ by the Kaplan-Meier technique.

The duration of platelet response was defined as the number of days from the day the platelet count reached or exceeded $50 \times 10^{9} / 1$ to either the first day the platelet count fell to $<20 \times 10^{9} / 1$ or the last day with available platelet count data, whichever occurred first. The median and a two-sided $95 \%$ non-parametric $\mathrm{CI}$ for the duration of platelet response were calculated. Medians, quartiles and their non-parametric two-sided $95 \% \mathrm{CI}$ were used to describe the maximum platelet count which was defined as the highest platelet count achieved on or after day 5 .

The median time to complete cessation of any hemorrhage was estimated by the Kaplan-Meier method (and included the two-sided 90\% CI for the median). This analysis was performed for the subset of subjects who presented with hemorrhages on day 1 . The time period for the regression of hemorrhages was expressed in integer days. The day when the regression of hemorrhage occurred was defined as the first day when all the subject's bleeding-related AEs had stopped and no new bleeding was reported to have started on that day.

\section{Results}

23 subjects were enrolled and treated (SADS). All 23 subjects were white Europeans, 13 were male, 10 were female. Age ranged between 18 and 68 years with a median of 49 years, body weight ranged from 58 to $116 \mathrm{~kg}$ with a median of $80 \mathrm{~kg}$. The most frequent disorders besides ITP and related disorders reported in the medical history (SADS) were cardiovascular disorders (10 subjects). 9 subjects had a history of hypertension. In 7 of these, mild or moderate hypertension was determined at enrolment. 9 subjects in the SADS had previously

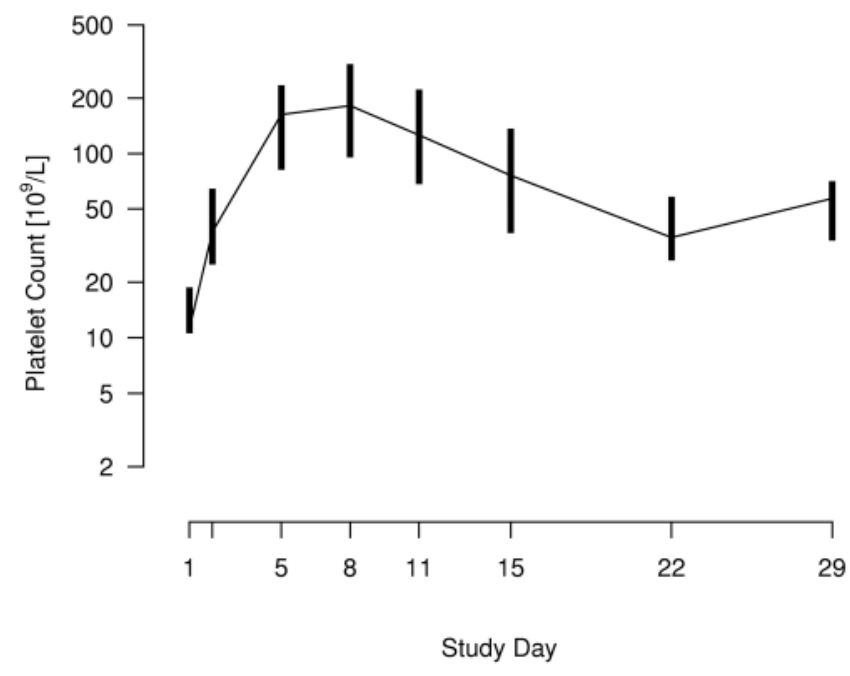

Fig. 1. Course of platelet counts in the treatment responders $(n=15)$ of the Per-Protocol Analysis Data Set. Median platelet counts and their 95\% CIs are shown.

had a splenectomy, and 9 subjects had been receiving systemic corticosteroids in doses equivalent to $20 \mathrm{mg}$ or less of prednisone daily in the 2 weeks preceding the first treatment. 8 subjects continued steroid treatment at steady or decreasing doses during the treatment and follow-up period. 2 of the 23 subjects did not meet all selection criteria and were excluded from the PADS $(n=21)$.

\section{Efficacy}

15 of the 21 subjects $(71.4 \%, 95 \%$ CI for proportion $50.0-86.2 \%$ ) in the PADS responded to treatment, while the number of treatment responders was 17 of 23 subjects $(73.9 \%$, 95\% CI for proportion 53.5-87.5\%) in the FADS. Box plots of platelet counts for the treatment responders of the PADS throughout the study are displayed in figure 1.

The median platelet count in both the PADS and the FADS (including treatment responders and non-responders) was $\geq 50 \times 10^{9} / 1$ by study day 5 (median $85 \times 10^{9} / 1$, in the 2 analysis data sets). Eleven subjects in the PADS presented with an increase to $>100 \times 10^{9} / 1$, and 8 subjects also reached a platelet count of $>200 \times 10^{9} / 1$ over the course of the study. In the FADS, 12 subjects achieved a platelet count of $>100 \times 10^{9} / 1$, and 9 reached $>200 \times 10^{9} / 1$. The highest median platelet count among treatment responders in the PADS and the FADS was $182 \times 10^{9} / 1$ (range $\left.17-435 \times 10^{9} / 1\right)$, observed on day 8 . The median platelet count on day 5 in treatment responders in either analysis data set was $163 \times 10^{9} / 1$ (range $\left.42-271 \times 10^{9} / 1\right)$. All of the treatment responders in the PADS and the FADS achieved a platelet count of $\geq 50 \times 10^{9} / 1$ by day 8 (within 7 days of initiation of treatment). 14 treatment responders in the PADS (93.3\%) and 15 in the FADS (88.2\%) achieved this platelet count as early as day 5 (i.e. within 4 days of treatment initiation). The median duration of platelet response was 25 
days for the treatment responders in both the PADS and the FADS (95\% CI 21-28 and 22-28, respectively).

Five subjects in the PADS and 6 in the FADS presented with a hemorrhage on day 1 , i.e. the day of the onset of the initial study drug treatment course. The median time to regression of the hemorrhage was 4 days (90\% CI 0-4 days) in the PADS and 2 days ( $90 \%$ CI $0-4$ days) in the FADS.

Of the 6 non-responders to study drug treatment observed in the current study, 5 received a booster dose in the 2 weeks after initiation of the first infusion. With one exception, none of these subjects achieved a platelet count of $\geq 50$ $\times 10^{9} / 1$ after receiving a booster dose. In the subject that did achieve a platelet count of $\geq 50 \times 10^{9} / 1$ the increase was most likely due to concomitant therapies for ITP initiated by the investigator when the platelet count remained low after IGIV administration.

\section{Safety and Tolerability}

A total of 81 infusions of IGIV $10 \%$ (initial treatment course and booster) were administered during the study. The total dose of $2 \mathrm{~g}$ of IGIV $10 \% / \mathrm{kg}$ was to be given within a treatment course of 2-5 consecutive days. The majority of the subjects treated (SADS) received the total dose in 2 days (12 of 23). Distribution of treatment courses and amount of product are shown in table 1 . The duration of individual infusions of the initial treatment course ranged from 2.0 to $6.1 \mathrm{~h}$ (median $4.0 \mathrm{~h}$ ), the minimum initial infusion rate was $0.35 \mathrm{ml} / \mathrm{kg} / \mathrm{h}$, the highest maximum infusion rate was $8 \mathrm{ml} / \mathrm{kg} / \mathrm{h}$. Details of infusion rates are shown in table 2.

A total of 84 AEs were reported in 18 subjects. Only 1 serious adverse event (SAE) was reported. This was a prolongation of hospitalization due to the observation of a hematoma in the right thigh and petechiae in a subject who was non-responsive to study drug treatment. The SAE was considered by the investigator to be unrelated to the use of the study drug. The majority ( 68 of 83 , i.e. $81.9 \%$ ) of the non-serious AEs reported were mild, 11 (13.3\%) were moderate, and 4 (4.8\%) were severe. 40 of the reported non-serious AEs were considered by the investigators to be related to the use of the study drug. Of these, 35 (87.5\%) were mild, 3 (7.5\%) were moderate, and $2(5.0 \%)$ were severe. The most frequently reported related AE was headache followed by pyrexia (table 3). 6 of 23 subjects $(26.1 \%)$ experienced hemorrhages which began after the first infusion of the study drug. Bleedings reported included: contusion (1 subject, $4.3 \%$ ), epistaxis (3 subjects, $13.0 \%$ ), gingival bleeding (2 subjects, $8.7 \%$ ), hematoma (2 subjects, $8.7 \%$ ), non-specific hemorrhage (3 subjects, $13.0 \%$ ) and petechiae (3 subjects, 13.0\%). Several subjects had more than one type of bleeding. All 23 subjects analyzed (SADS) tested negative in the direct Coombs' tests at baseline. In the followup tests, 3 subjects $(13.0 \%)$ tested positive in the direct Coombs' test. No AEs involving hemolysis were reported during the study and no evidence of drug-induced hemolysis for these cases was found.
Table 1. Summary of dose administered - SADS

\begin{tabular}{llllll}
\hline Parameter / Statistic & \multicolumn{2}{l}{ Infusions, $\mathrm{n}$} & \multirow{2}{*}{ Total } \\
\cline { 2 - 5 } & 2 & 3 & 4 & 5 & \\
\hline $\begin{array}{l}\text { Subjects, n } \\
\text { Total dose infused, g }\end{array}$ & 12 & 4 & 2 & 5 & 23 \\
$\quad \begin{array}{llllll}\text { Mean } \\
\text { SD }\end{array}$ & 152 & 192 & 204 & 162 & 166 \\
$\begin{array}{l}\text { Total dose per kg infused, g/kg } \\
\quad \text { Mean }\end{array}$ & 28 & 42 & 40 & 23 & 34 \\
$\quad$ SD & 1.99 & 2.00 & 2.01 & 2.00 & 2.00 \\
Total volume infused, $\mathrm{ml}$ & 0.04 & 0.01 & 0.01 & 0.04 & 0.03 \\
$\quad$ Mean & 1,533 & 1,938 & 2,050 & 1,650 & 1,674 \\
$\quad$ SD & 281 & 399 & 424 & 235 & 340 \\
\hline
\end{tabular}

Table 2. Summary of infusion rates (initial treatment course)

\begin{tabular}{llll}
\hline Statistic & $\begin{array}{l}\text { Duration of } \\
\text { infusion, } \mathrm{h}\end{array}$ & $\begin{array}{l}\text { Initial infusion } \\
\text { rate, } \mathrm{ml} / \mathrm{kg} / \mathrm{h}\end{array}$ & $\begin{array}{l}\text { Maximum infusion } \\
\text { rate, } \mathrm{ml} / \mathrm{kg} / \mathrm{h}\end{array}$ \\
\hline Mean & 3.9 & 0.55 & 3.98 \\
SD & 1.0 & 0.18 & 1.81 \\
Median & 4.0 & 0.50 & 4.00 \\
Min & 2.0 & 0.35 & 0.80 \\
Max & 6.1 & 1.04 & 8.00 \\
\hline
\end{tabular}

Table 3. AEs related to study drug

\begin{tabular}{lll}
\hline Related AEs & $\begin{array}{l}\text { Frequency } \\
\text { of occurrence }\end{array}$ & $\begin{array}{l}\text { Subjects, } \\
\mathrm{n}\end{array}$ \\
\hline Headache & 11 & 8 \\
Pyrexia & 7 & 7 \\
Increase in body temperature & 2 & 2 \\
Hypertension & 3 & 3 \\
Insomnia & 2 & 1 \\
Nausea & 2 & 2 \\
Phlebitis & 2 & 2 \\
Pain in extremity & 2 & 1 \\
Infusion site pain, rash, dermatitis, & 1 each & 1 each \\
urticaria, flushing, back pain, & & \\
burning sensations, anxiety, & & \\
rhinorrhea & & \\
\hline
\end{tabular}

\section{Discussion}

Following the first report on the transient increase of platelet counts in patients with ITP after IGIV [26], IGIV has been widely used in the treatment of this disease. Taking into account the different modes of dosing in clinical practice in recent years, it was decided that a total dose of $2 \mathrm{~g} / \mathrm{kg}$ given over 2-5 days was to be administered during this study. Of the 23 subjects treated, the majority received the study product over a 2-day period. 
The rate of treatment responders in the study $(71.4 \%)$ is in agreement with data reported in the literature. In a similar study in adults with chronic ITP, treatment response defined as platelet increase to $\geq 50 \times 10^{9} / 1$ was achieved in $73.4 \%$ of the subjects [35]. A platelet increase to $\geq 50 \times 10^{9} / 1$ was attained in $75 \%$ of the subjects who received a nanofiltered preparation as reported in a study comparing 2 different IGIV preparations [36]. In a study comparing two $12 \%$ immunoglobulin preparations, a platelet increase to $\geq 50 \times 10^{9} / 1$ was seen in 75 and $71 \%$ of the subjects [37]. The total dose of IGIV administered in these studies was the same we used in our study. A response rate of $75 \%$ was also reported in a study on adult ITP patients, some of whom were concurrently on corticosteroids [38]. Response to treatment in that study was defined as platelet increase by $\geq 30 \times 10^{9} / 1$. Platelet response rates vary from study to study and can range from 66.7 to $100 \%$ [36, 39]. Eleven subjects in the current study achieved an increase to $>100 \times 10^{9} / 1$, and 8 reached a platelet count of $>200 \times 10^{9} / 1$ over the course of the study. The highest median platelet count in treatment responders was $182 \times 10^{9} / 1$ observed on day 8 . The median platelet count in treatment responders on day 5 after the start of the IGIV $10 \%$ treatment course was $163 \times 10^{9} / 1$. In a similar study, 1 week after the initiation of treatment, the mean maximum platelet count for responders was $163 \times 10^{9} / 1$ [38]. Starting with mean platelet counts of $30 \times 10^{9} / 1$, a mean platelet increment of $89 \times 10^{9} / 1$ was observed in the treatment responders of another study after a 2-day schedule (1 $\mathrm{g} / \mathrm{kg} /$ day) of IGIV [40].

Booster treatment of non-responders was not effective in our study. It has been reported in previous studies that, in subjects that did not initially demonstrate an adequate response, a continuation of IGIV treatment made little difference to the platelet count [38]. In the current study, 9 of 23 subjects had been splenectomized prior to study entry. Four of 9 subjects who had previously been splenectomized presented with an extremely low platelet count $\left(\leq 7 \times 10^{9} / 1\right)$ at baseline. Two of these were non-responders and probably belong to the group of ITP patients who are generally therapy resistant, i.e. are unresponsive to splenectomy and all treatments they receive or require high-dose or additional therapy [41-43]. The other 2 were responders and received corticosteroid treatment both before and during the study.

The platelet response observed in the current study was rapid. The median time to platelet response $\left(\geq 50 \times 10^{9} / 1\right.$ in at least $50 \%$ of the subjects) was estimated as 4 days from the beginning of the first treatment. 14 of 15 treatment responders $(93.3 \%)$ achieved a platelet count of $\geq 50 \times 10^{9} / 1$ within 4 days of treatment initiation. In a similar study, a median time to platelet response (platelet count $\geq 50 \times 10^{9} / 1$ ) of 3 days was reported [44]. Mean times to platelet response of 4 and 5 days were observed in a study comparing 2 different IGIV products in patients with chronic ITP [36, 37].

The median duration of platelet response observed in the current study was 25 days for the treatment responders and was defined as the duration from the day the platelet count reached or exceeded $50 \times 10^{9} / 1$ to either the first day of the platelet count falling to $<20 \times 10^{9} / 1$ or the last day with available platelet count data. Other studies using the same dose of IGIV reported durations of platelet response ranging from a mean of 10 days with platelet counts of $>50 \times 10^{9} / 1$ [36] to 25.5 days (median) with platelet counts above the baseline level [44]. A median duration of platelet levels above $50 \times 10^{9} / 1$ of 6 and 10 days was reported for a nanofiltered liquid product and its lyophilized predecessor preparation in a study comparing 2 IGIV preparations [37]. Platelet counts of $>30 \times 10^{9} / 1$ for 26 days were reported by Newland et al. [38], and in a very recent study comparing 2 different IGIV preparations, platelet counts of $\geq 50 \times 10^{9} / 1$ were maintained for at least 7 days or more in 74 and $60 \%$ of the subjects, respectively [45].

The data on AEs indicate that treatment with IGIV $10 \%$ is well tolerated. A total of 84 AEs were reported in 18 subjects, i.e. $78.3 \%$ of all subjects. Only $1 \mathrm{SAE}$ was reported, which was classified by the investigator as unrelated to the use of the study drug. The majority of the non-serious AEs reported were mild. 13 subjects $(56.5 \%)$ reported $40(48.2 \%)$ non-serious AEs that were considered by the investigators to be related to the use of the study drug. Comparable AE rates after administration of high-dose IGIV to ITP patients have been reported in the literature $[37,38,44]$. The AEs most frequently related to the use of IGIV $10 \%$ were headache and pyrexia. The types of AEs considered to be causally related to the use of the study drug in the current study are known from previous experience with IGIV; other studies also reported headache and pyrexia among the most frequently-occurring AEs $[37,44,45] .3$ of the 23 subjects $(13.0 \%)$ treated with the study drug tested positive in the direct Coombs' test, but no evidence of drug-induced hemolysis was found. In a study with high-dose IGIV for the treatment of ITP, approximately one third of the patients presented with a positive direct antiglobulin test without evidence of clinically significant hemolysis [45]. The results obtained in this study demonstrate that IGIV $10 \%$ is effective in the treatment of adult subjects with chronic ITP and is well tolerated.

\section{Conflict of Interest Statement}

The study was sponsored by Baxter AG, Vienna, Austria. Authors for whom Baxter, Vienna, Austria, is given as affiliation are employees of the study sponsor. 


\section{References}

1 Miller JLC, Petteway SR, Lee DC: Ensuring the pathogen safety of intravenous immunoglobulin and other human plasma-derived therapeutic proteins. J Allergy Clin Immmunol 2001;108:S91-S94.

2 Chamberland ME: Surveillance for bloodborne infections. Thromb Haemost 1999;82:494-499.

3 Chamberland ME, Alter HJ, Busch MP, Nemo G, Ricketts M: Emerging infectious disease issues in blood safety. Emerg Infect Dis 2001;7(suppl 3): 552-553.

4 Dodd RY, Leiby DA: Emerging infectious threats to the blood supply. Annu Rev Med 2004;55 191-207.

5 Van Hulst M, de Wolf JTM, Staginnus U, Ruitenberg EJ, Postma MJ: Pharmaco-economics of blood transfusion safety: review of the available evidence. Vox Sang 2002;83:146-155.

6 Hoots WK: History of plasma-product safety. Transfus Med Rev 2001;15(2 suppl 1):3-10.

7 Barbara J: Why 'safer than ever' may not be quite safe enough. Transfus Med Hemother 2004;31 (suppl 1):2-10.

8 Horowitz B, Prince AM, Hamman J, Watklevicz C Viral safety of solvent/detergent-treated blood products. Blood Coagul Fibrinolysis 1994;5(suppl 3):S21-S28.

9 Kreil TR, Berting A, Kistner O, Kindermann J: West Nile virus and the safety of plasma derivatives: verification of high safety margins, and the validity of predictions based on model virus data. Transfusion 2003;43:1023-1028.

10 Hamamoto Y, Harada S, Kobayashi S, Yamaguchi K, Iijima H, Manabe S, Tsurumi T, Aizawa H, Yamamoto N: A novel method for removal of human immunodeficiency virus: filtration with porous polymeric membranes. Vox Sang 1989;56:230-236.

11 Yuasa T, Ishikawa G, Manabe S, Sekiguchi S, Takeuchi K, Miyamura T: The particle size of hepatitis $\mathrm{C}$ virus estimated by filtration through microporous regenerated cellulose fibre. J Gen Virol 1991;72(Pt 8):2021-2024.

12 Hamalainen E, Suomela H, Ukkonen P: Virus inactivation during intravenous immunoglobulin production. Vox Sang 1992;63:6-11.

13 Kempf C, Jentsch P, Poirier B, Barré-Sinoussi F, Morgenthalter JJ, Morell A, Germann D: Virus inactivation during production of intravenous immunoglobulin. Transfusion 1991;31:423-427.

14 Louie RE, Galloway CJ, Dumas ML, Wong MF, Mitra G: Inactivation of hepatitis C virus in low $\mathrm{pH}$ intravenous immunoglobulin. Biologicals 1994;22: 13-19.

15 Reid KG, Cuthbertson B, Jones AD, McIntosh RV: Potential contribution of mild pepsin treatment at $\mathrm{pH} 4$ to the viral safety of human immunoglobulin products. Vox Sang 1988;55:75-80.

16 Schroeder DD, Mozen MM: Australia antigen: distribution during Cohn ethanol fractionation of human plasma. Science 1970;168:1462-1464.

17 Wells MA, Wittek AE, Epstein JS, Marcus-Sekura C, Daniel S, Tankersley DL, Preston MS, Quinnan GV Jr: Inactivation and partition of human T-cell lymphotrophic virus, type III, during ethanol fractionation of plasma. Transfusion 1986;26:210-213.

18 Zolton RP, Padvelskis JV: Evaluation of an ion-exchange procedure for removal of hepatitis type $B$ contamination from human gamma globulin products. Vox Sang 1984;47:114-121.
19 Zolton RP, Padvelskis JV, Kaplan PM: Removal of hepatitis B virus infectivity from human gamma globulin prepared by ion-exchange chromatography. Vox Sang 1985;49:381-389.

20 Kühne T, Imbach P: Management of children with acute and chronic immune thrombocytopenic purpura. Transfus Sci 1998;19:261-268.

21 Robak T, Robak P: Treatment options for autoim mune cytopenias. Transfus Med Hemother 2004;31 332-340.

22 Woods VL, Kurata Y, Montgomery RR, Tani P Mason D, Oh EH, McMillan R: Autoantibodies against platelet glycoprotein $\mathrm{Ib}$ in patients with chronic immune thrombocytopenic purpura. Blood 1984;64:156-160.

23 McMillan R: The pathogenesis of chronic immune (idiopathic) thrombocytopenic purpura. Sem Hematol 2000;37(suppl 1):5-9.

24 Karpatkin S: Autoimmune (idiopathic) thrombocytopenic purpura. Lancet 1997;349:1531-1536.

25 George JN, Woolf SH, Raskob GE, Wasser JS, Aledort LM, Ballem PJ, Blanchette VS, Bussel JB, Cines DB, Kelton JG, Lichtin AE, McMillan R, Okerbloom JA, Regan DH, Warrier I: Idiopathic thrombocytopenic purpura: a practice guideline developed by explicit methods for the American Society of Hematology. Blood 1996;88:3-40.

26 Imbach P, Barandun S, d'Apuzzo V, Baumgartner C, Hirt A, Morell A, Rossi E, Schöni M, Vest M, Wagner HP: High-dose intravenous gammaglobulin for idiopathic thrombocytopenic purpura in childhood. Lancet 1981;i:1228-1231.

27 Godeau B, Lesage S, Divine M, Wirquin V, Farcet JP, Bierling P: Treatment of adult chronic autoimmune thrombocytopenic purpura with repeated high-dose intravenous immunoglobulin. Blood 1993;82:1415-1421.

28 Imbach P, Morell A: Idiopathic thrombocytopenic purpura (ITP): immunomodulation by intravenous immunoglobulin (IVIG). Int Rev Immunol 1989;5: 181-188.

29 Kiernan M, O'Dwyer R, McCann SR: The use of intravenous immunoglobulin in patients with immune thrombocytopenia. Clin Lab Haematol 1986; 8:21-26.

30 Lang JM, Faradji A, Giron C, Bergerat JP, Oberling F: High-dose intravenous IgG for chronic idiopathic thrombocytopenic purpura in adults. Blut 1984;49:95-99.

31 Solal-Celigny P, Bernard JF, Herrera A, Boivin P Treatment of adult autoimmune thrombocytopenic purpura with high-dose intravenous plasmincleaved gammaglobulins. Scand J Haematol 1983; 31:39-44.

32 Schmidt RE, Budde U, Bröschen-Zywietz C, Schäfer G, Mueller-Eckhardt C: High dose gammaglobulin therapy in adults with idiopathic thrombocytopenic purpura (ITP). Clinical effects. Blut 1984; 48:19-25.

33 Macey MG, Macintyre EA, Newland AC: Red cell sequestration during high dose intravenous immunoglobulin in idiopathic thrombocytopenic purpura. Blut 1986;53:77-87.

34 Newcombe RG: Two-sided confidence intervals for the single proportion: comparison of seven methods. Stat Med 1998;17:857-872.
35 Choi CW, Kim BS, Seo JH, Shin SW, Kim YH, Kim JS, Sohn SK, Kim JS, Shin DG, Ryoo HM, Lee KH, Lee JJ, Chung IJ, Kim HJ, Kwak JY, Yim CY, Ahn JS, Lee JA, Park YS: Response to high-dose intravenous immune globulin as a valuable factor predicting the effect of splenectomy in chronic idiopathic thrombocytopenic purpura patients. Am J Hematol 2001;66:197-202.

36 Wolf HH, Davies SV, Borte M, Caulier MT, Williams PE, Bernutz HV, Egner W, Sklenar I, Adams C, Späth P, Morell A, Anresen I: Efficacy, tolerability, safety, and pharmacokinetics of a nanofiltered intravenous immunoglobulin: studies in patients with immune thrombocytopenic purpura and primary immunodeficiencies. Vox Sang 2003;84:45-53

37 Borte M, Davies SV, Touraine J-L, Farber C-M, Lipsic T, Adams C, Späth P, Bolli R, Morell A, Andresen I: Clinical properties of a novel liquid intravenous immunoglobulin: studies in patients with immune thrombocytopenic purpura and primary immunodeficiencies. Transfus Med Hemother 2004; 31:126-134.

38 Newland AC, Burton I, Cavenagh JD, Copplestone A, Dolan G, Houghton J, Reilly T: Vigam-S, a solvent/detergent-treated intravenous immunoglobulin in idiopathic thrombocytopenic purpura. Transfus Med 2001;11:37-44.

39 Korninger C, Panzer S, Graninger W, Neumann E Niesser H, Lechner K, Deutsch E: Treatment of severe chronic idiopathic thrombocytopenic purpura in aduts with high-dose intravenous gammaglobulin. Scand J Haematol 1985;34:128-132.

40 Kurlander R, Coleman RE, Moore J, Gockerman J, Rosse W, Siegal R: Comparison of the efficacy of a two-day and a five-day schedule for infusing intravenous gamma globulin in the treatment of im mune thrombocytopenic purpura in adults. Am J Med 1987;83:17-24.

41 Karpatkin S: Autoimmune (idiopathic) thrombocytopenic purpura. Lancet 1997;349:1531-1536.

42 Ruivard M, Caulier MT, Vantelon JM, Tournilhac O, Schaeffer A, Godeau B, Bierling P: The re sponse to high-dose intravenous immunoglobulin or steroids is not predictive of outcome afte splenectomy in adults with autoimmune thrombocytopenic purpura. B J Haematol 1999;105: 1130-1132.

43 McMillan R, Durette C: The long-term outcome of adult chronic ITP patients who fail splenctomy. Blood 2004;104:956-960.

44 Colovic M, Dimitrijevic M, Sonnenburg C, Suvajdzic N, Donfrid M, Bogdanovic A: Clinical efficacy and safety of a novel intravenous immunoglobulin preparation in adult chronic ITP. Hematol J 2003; 358-362.

45 Bussel JB, Eldor A, Kelton JG, Varon D, Brenner B, Gillis S, Angiolillo A, Kulkarni R, Abshirel TC, Kelleher J: IGIV-C, a novel intravenous immunoglobulin: Evaluation of safety, efficacy, mechanisms of action, and impact on quality of life. Thromb Haemost 2004;91:771-778. 